Ishan, J.R.P., De Silva, N. and Withanage, K.T., 2019. Use of shipping container housing concept as a low cost housing solution for resettlement projects in urban areas. In: Sandanayake, Y.G., Gunatilake, S. and Waidyasekara, A. (eds). Proceedings of the $8^{\text {th }}$ World Construction Symposium, Colombo, Sri Lanka, 8-10 November 2019, pp. 608-617. DOI: doi.org/10.31705/WCS.2019.60. Available at: https://2019.ciobwcs.com/papers

\title{
USE OF SHIPPING CONTAINER HOUSING CONCEPT AS A LOW COST HOUSING SOLUTION FOR RESETTLEMENT PROJECTS IN URBAN AREAS
}

\author{
J.R.P. Ishan ${ }^{1}$, Nayanathara De Silva ${ }^{2}$ and K.T. Withanage ${ }^{3}$
}

\begin{abstract}
Today, one-third of the world's urban population live in slums and shanties., while prioritizing adequate housing as their basic need. They face a lack of basic needs such as clean air, water, sanitation and healthy foods. Rapid urbanization leads to increased demand for condominiums and focused on slum-free cities to get maximum utilization of high potential prime lands. As a solution, shipping container housing (SCH) concept has been successfully practiced in many countries in all over the world to promote low cost housing (LCH) for resettlement projects. Therefore, this research intends to explore the use of SCH concept as a LCH for permanent resettlement projects in urban areas of Sri Lanka. A comprehensive literature synthesis emphasizes the suitability of SCH concept as a LCH solution and it proved that approximately $60 \%$ of construction cost can be saved by using this SCH concept over the traditional construction methods. Selected case study for this research was "low income permanent resettlement programme in Colombo city". Finally, the study revealed that use of SCH concept as a LCH solution for resettlement projects in Colombo will not be a feasible solution due to the specific retarding factors from the low income groups, specific characteristics of shipping container boxes and climatic conditions of Sri Lanka. Moreover, this study was very useful for the governing authorities to identify the leading alter factors between the theoretical concept and practical implementation of low income permanent resettlement projects in Sri Lanka.
\end{abstract}

Keywords: City; Low Cost Housing; Resettlement Projects; Shipping Container Housing.

\section{INTRODUCTION}

Resettlement can be identified as relocating a group of people who lived as refugees from the existing place to another protective novel place that accepting them and to provide permanent settlement and better living status (UNHCR, 2011). Resettlement is needed for those who were affected by war, social hazards, disasters and urban development projects. In the Sri Lankan context, low income slum communities were the mostly affected group due to urban development projects (Deheragoda, 2008).

\footnotetext{
${ }^{1}$ Department of Building Economics, University of Moratuwa, Sri Lanka,jrpishan@gmail.com

2 Department of Building Economics, University of Moratuwa, Sri Lanka, endds@uom.lk

${ }^{3}$ Department of Building Economics, University of Moratuwa, Sri Lanka, kanchukathilakshana@gmail.com
} 
Recently the Sri Lankan government is going ahead with mega development projects in Colombo and other urban areas in the Western province under the Ministry of Mega polis and Western Development. As a result of this, a wide range of people will lose their shelter (Ministry of Megapolis and Western Development, 2015). Under these circumstances, permanent resettlement of these families with better living standards becomes one of the major challenges that has to be overcome immediately. According to the Cohen and Bradley (2010), obtaining an adequate, suitable, immediate, affordable and sustainable housing was very important to a successful integration into a new society, especially at an initial stage of a permanent resettlement (as cited in Forrest et al., 2013). Different types of resettlement projects can be identified depending on the scale of the resettlement, financial levels of people, use of land area, price of land, etc (Wijayasinghe, 2010).

The common methods used as LCH in other countries are to build low-rise modular homes, panelised homes, pre-cut homes and container homes (Ford et al., 2014). Therefore, shipping containers have been used as an alternative and sustainable housing construction method which fulfilled the above all requirements of low income communities (Islam et al., 2016).

Shipping containers were made out with standard dimensions including some in-built properties to convert them for an excellent modular structural component. According to the standards sizes of a container boxes, it starts from $20 \mathrm{ft}$. $\mathrm{X} 8 \mathrm{ft} .=160 \mathrm{ft}^{2}$ which is similar to living area or size of master bedroom of a conventional house (Martinez-Garcia, 2014). Further it has an environmentally friendly way of construction and able to act as sustainable and economical method of construction while saving traditional construction materials, construction cost and additional working spaces. Some of the countries have been successfully adopted this SCH concept such as Netherlands, USA, Qatar, China, Haiti and etc. (Meinhold, 2010; Winter, 2013; Simon, 2014).

However, in Sri Lanka, no research has been carried out to analyse the suitability of shipping container housing concept for permanent resettlement projects as an alternative solution. Therefore, with the aim of filling this research gap, this research was conducted to investigate the use of shipping container housing concept as a $\mathrm{LCH}$ solution for permanent resettlement projects in the Colombo region.

\section{LITERATURE SYNTHESIS}

In mid of 1950s, governments of South Asian countries were attempted to fulfil the housing and shelter needs of the poor communities and they developed housing policies with the aim of supporting public backed by public finance (Joshi and Sohail, 2014). However, the rapid urbanization causes the lack of adequate and affordable housing, lack of pro-active approach to development and it was contributed to higher population densities to proliferation of slums and informal settlements in the most urbanized cities in these regions (Wijayasinghe, 2010). Often, living in these slums and shanties can be affected to both physical and psychological dangers (Brown, 2003).

\subsection{RESETTLEMENT}

Resettlement is the mechanism of compensation of the population affected by a large industrial investment (Bolt and Stănculescu, 2012). Moreover, resettlement involves transfer communities from the origin to a specific newly built area as destination. 
Basically, resettlement covers all direct economic and social losses resulting from land acquisition and restrictions of access, together with the consequent compensatory and remedial measures (World Bank, 2004). There are several types of resettlements based on the decision of resettled population and inducement as voluntary resettlement, involuntary resettlement, disaster induced resettlement and development induced resettlement (Forrest et al., 2013).

\subsection{APPLICATION OF SHIPPING CONTAINERS}

In the past, shipping containers were used as stores and tool sheds without any modifications. In 1987, Phillip C. Clark obtained a patent for modifying shipping container boxes for habitable and productive buildings.

Through this patent, shipping container architecture were established by attaching one or more container boxes on a foundation with all infrastructural elements such as inner side walls, roofs, ceilings, doors and windows. Further Urban Space Management firm in London was completed a project called "container city" at 2001. Container city provided example for this alternative method of construction which can be used as living spaces, work spaces, offices, youth centres, studios and etc. (as cited in Vijayalaxmi, 2010). According to Abrasheva et al. (2012), shipping containers drive through a possible great success in the construction business because of its system based advantages such as wide availability, ease to prefabrication, mobility and modularity, short planning and implementation periods and low cost of construction.

\subsection{Shipping Containers Housing ConcePt AS A LCH Solution}

Sawyers (2008) have figured major reasons of using shipping container architecture for construction as;

- Modular design - has the same width, standard height and length, can be combined into larger structures and simplifies design and planning.

- Strength and durability - designed to carry heavy loads and to be stacked in high columns, resist harsh environments, such as on ocean-going vessels and long distance transportation on roads.

- Low cost of labour - Lower labour cost than conventional construction methods for the welding and cutting of shipping containers.

- Low initial cost - used shipping containers are available at very low prices.

- Transport convenience - Can be conveniently transported by ship, truck or rail.

\section{RESEARCH METHODOLOGY}

In this research, single case study approach was used due to lack of available practical cases and concept is very new to Sri Lankan industry. Therefore, this was limited to the exploring of use of SCH concept as a LCH solution for permanent resettlement projects in Colombo region only.

\subsection{Data Collection Method}

\subsubsection{Data Collection - Phase 01}

A comprehensive documentary survey was carried out under the phase 01 to collect the quantitative data as secondary data, with the help of Urban Development Authority and 
shipping container house manufacturers. Cost data of existing housing units were obtained from the quantity surveying (QS) division and detailed floor plans were obtained from planning and designing (P\&D) division of the Urban Development Authority. After critically evaluation and analysis, new shipping container house was proposed by using 3 shipping container units. Summary of collected data and their sources were summarized in Table 1.

Table 1: Sources and collected information in phase 01

Document Sources/ Information Source Collected Information

Obtained from the Urban Development Authority

- Annual reports-Ministry of Finance $(2011,2012,2013,2014,2015,2016)$

- Monthly and quarterly progress reports prepared by the Urban Development Authority

- Urban regeneration programme project plan (First edition and second edition)

- Website of the Urban Development Authority

- Contractual documents obtained from the QS division of the Urban Development Authority
- Summary of cost provisions for resettlement programme

- Progress and delaying causes of the resettlement programme

- Details regarding the expected number of beneficiaries, expected progress measurements and floor plans of the housing units

- Summary of resettlement programme

- Cost details of completed part of project, contractual disputes of ongoing projects and delay causes

\section{Obtained from the Shipping container home manufacturer}

- Bill of quantities of completed projects

- Estimate for proposed SCH unit
- Average cost details and major cost components of a shipping container house

- Cost details of SCH unit

\subsubsection{Data Collection - Phase 02}

At the end of the phase 01 , there were few possible factors were identified that can be affected to success or failure of the solution proposed. To validate those qualitative factors as primary data, seven expert interviews were carried out with expert in shipping container manufacturing industry, civil engineers and key personnel representing Urban Development Authority as shown in Table 2.

Table 2: Details of respondents in phase 02

\begin{tabular}{|c|c|c|}
\hline Respondent & Affiliation & Background \\
\hline R1 & $\begin{array}{l}\text { Shipping container building } \\
\text { manufacturing industry }\end{array}$ & $\begin{array}{l}\text { Shipping container house manufacturer who } \\
\text { has more than } 15 \text { years of experience in } \\
\text { industry }\end{array}$ \\
\hline $\mathrm{R} 2$ & Freelancer & $\begin{array}{l}\text { Charted structural engineer who has more } \\
\text { than } 20 \text { years of experience in industry }\end{array}$ \\
\hline R3 & Urban Development Authority & $\begin{array}{l}\text { Director of a one phase (low income) of } \\
\text { resettlement programme }\end{array}$ \\
\hline
\end{tabular}




\begin{tabular}{lll}
\hline Respondent & \multicolumn{1}{c}{ Affiliation } & \multicolumn{1}{c}{ Background } \\
\hline R4 & Urban Development Authority & $\begin{array}{l}\text { Director of a one phase (middle income) of } \\
\text { resettlement programme } \\
\text { R5 }\end{array}$ \\
Urban Development Authority & $\begin{array}{l}\text { Deputy director of resettlement and senior } \\
\text { architect }\end{array}$ \\
R6 & Urban Development Authority & Senior quantity surveyor \\
R7 & Urban Development Authority & Planning engineer \\
\hline
\end{tabular}

\subsection{DATA ANALYSIS MethodS}

Quantitative data (i.e. cost data and progress data) were analysed through necessary mathematical analysis and qualitative data were analysed with content analysis technique using NVivo software (version 11).

\section{DATA ANALYSIS AND FINDINGS}

\subsection{Case Profile}

By a survey which has been conducted in the year 2010 and 2011, Urban Development Authority has identified a total number of 68,812 families living in 1,499 underserved settlements which haven't a healthy environment for human habitation and access to basic infrastructure facilities such as clean water, electricity, sanitation etc. In response, the Urban Development Authority planned out a program to construct 68,000 housing units for resettlement of these shanty dwellers with a view to liberating the prime lands presently occupied by them as well as uplifting the living standards of the occupants. This strategy would also help to clear out most of the derelict areas in the city while releasing these lands for urban developments. The urban regeneration project has been started with the aim of constructing LCH units with $550 \mathrm{ft}^{2}$ usable floor area as shown in Figure 1.

Further it intended to liberate 900 acres of valuable lands through relocation and to utilize 300 acres for re-housing projects, 150 acres for recreational and 450 acres for mix development projects.

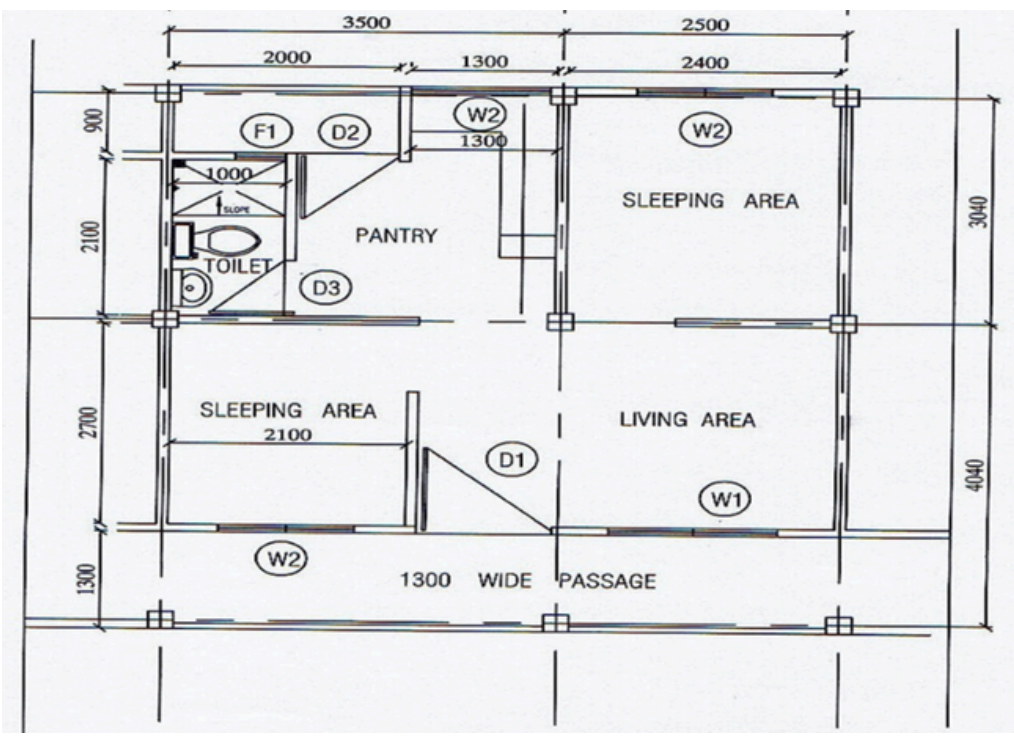

Figure 1: Typical house unit plan of resettlement project (Source: Urban Development Authority, 2012) 
Urban Development Authority hopes to recover the one million rupees (Rs.1, 000,000.00) of the total construction cost (Rs.4, 500,000.00) of a housing unit through an affordable interest free loan system from the resettled families. This amount will be recovered at the end of 30 years of time. Under this urban regeneration programme, 5859 number of houses have been constructed up to now under Phase 01 as shown in Table 3.

Table 3: Completed housing units

\begin{tabular}{lllll}
\hline No & Location & $\begin{array}{l}\text { No of } \\
\text { units }\end{array}$ & $\begin{array}{l}\text { Approximate construction } \\
\text { cost (Rs.) }\end{array}$ & Completed year \\
\hline 1 & Dematagoda & 500 & $1,220,707,371.16$ & 2013 \\
2 & Orugodawatta & 34 & $64,282,940.86$ & 2014 \\
3 & Wanathamulla & 718 & $2,291,796,269.58$ & 2014 \\
4 & Wanathamulla & 430 & $1,372,524,228.30$ & 2014 \\
5 & Bloumendhal & 366 & $1,039,250,144.38$ & 2014 \\
6 & Wellawatta & 118 & $487,511,150.10$ & 2014 \\
7 & Henamulla & 1137 & $3,228,511,767.39$ & 2014 \\
8 & Fergusion road & 872 & $2,528,819,327.20$ & 2014 \\
9 & Edirisinghwatta & 546 & $1,597,276,976.54$ & 2014 \\
10 & Salamulla & 216 & $597,645,570.39$ & 2014 \\
11 & Pradeepa mawatha & 266 & $759,428,706.54$ & 2016 \\
12 & Thachchiwatta & 68 & $150,244,845.90$ & 2017 \\
13 & Maligawatta & 192 & $285,102,576.53$ & 2017 \\
14 & Salamulla & 396 & $968,024,939.47$ & 2017 \\
Total & & 5859 & & \\
\hline
\end{tabular}

Source: (Urban Development Authority, 2017)

In addition to that there are 8 ongoing projects under phase 01 (4112 houses) and 7 ongoing projects under phase 02 (5947 houses). After completion of these ongoing phases, 15918 numbers of housing units will be added to fulfil the housing requirement. Comparing to the construction programme Urban Development Authority has a challenge to build rest of 52082 number of housing units at the end of 2020 . It is nearly $76 \%$ of initial housing requirement.

\subsection{COST COMPARISON BETWEEN A CONVENTIONAL HOUSE AND A Proposed Shipping Container House}

\subsubsection{Cost of a Conventional House Unit}

Average unit cost of conventional housing unit which is calculated by the Urban Development Authority;

= Rs. $4200000 / 550 \mathrm{ft}^{2}=$ Rs. $7336 / \mathrm{ft}^{2}$

\subsubsection{Cost of a Proposed SCH Unit}

Cost details and the technical details were obtained from a shipping container home manufacturer who having more than 15 years of experiences with over 50 successfully completed project all over the Sri Lanka. Based on the proposal 3 numbers of $20 \mathrm{ft}$ 
container boxes were combined together $\left(480 \mathrm{ft}^{2}\right)$ and developed a housing unit designs which is providing $450 \mathrm{ft}^{2}$ usable floor area. Total cost for proposed $\mathrm{SCH}$ unit is shown in following Table 4.

Table 4: Cost estimation for the proposed SCH unit

\begin{tabular}{|c|c|c|c|c|c|}
\hline No & Description & Unit & Qty & Rate (Rs.) & Amount (Rs.) \\
\hline 1 & $\begin{array}{l}\text { Supplying of an empty shipping } \\
\text { container box including all taxes and } \\
\text { clearing charges from the custom }\end{array}$ & item & 1 & $585,000.00$ & $585,000.00$ \\
\hline 2 & $\begin{array}{l}\text { Modification cost including cutting, } \\
\text { welding, preparing surfaces, fixing box } \\
\text { bars for made openings and fixing } \\
\text { container boxes together }\end{array}$ & item & 1 & $240,000.00$ & $240,000.00$ \\
\hline 3 & $\begin{array}{l}\text { Cost of steel reinforcement for openings } \\
\text { of the unit }\end{array}$ & item & 1 & $240,000.00$ & $240,000.00$ \\
\hline 4 & $\begin{array}{l}\text { Insulation of the interior of shipping } \\
\text { container boxes as per the engineer's } \\
\text { instructions }\end{array}$ & item & 1 & $90,000.00$ & $90,000.00$ \\
\hline 5 & $\begin{array}{l}\text { Installation of electrical wiring and all } \\
\text { related equipment, fittings, switches, } \\
\text { socket outlets and luminaires }\end{array}$ & item & 1 & $80,000.00$ & $80,000.00$ \\
\hline 6 & $\begin{array}{l}\text { Installation of plumbing services } \\
\text { including all bathroom equipment, sink } \\
\text { and other fittings }\end{array}$ & item & 1 & $100,000.00$ & $100,000.00$ \\
\hline 7 & $\begin{array}{l}\text { protective paintings of the shipping } \\
\text { container including both inside and } \\
\text { outside }\end{array}$ & item & 1 & $210,000.00$ & $210,000.00$ \\
\hline 8 & Transportation and miscellaneous items & item & 1 & $200,000.00$ & $200,000.00$ \\
\hline \multicolumn{2}{|c|}{ Total Amount } & & & & $1,745,000.00$ \\
\hline
\end{tabular}

Source: Shipping container home manufacturer (2017)

Average unit cost of proposed housing unit;

= Rs. 1745 000/450 ft' $=$ Rs. 3 878/ $\mathrm{ft}^{2}$ (approximate)

Table 5: Cost comparison

\begin{tabular}{lccr}
\hline \multicolumn{1}{c}{ Housing solution } & No of houses & Cost of a housing unit (Rs) & \multicolumn{1}{c}{ Total cost (Rs) } \\
\hline Conventional solution & 52082 & $4,500,000.00$ & $234,369,000,000.00$ \\
Proposed solution & 52082 & $1,745,000.00$ & $90,883,090,000.00$ \\
& & & \\
\multicolumn{2}{l}{ Total saving (Approximately) } & & $\mathbf{1 4 3 , 4 8 5 , 9 1 0 , 0 0 0 . 0 0}$ \\
\hline
\end{tabular}

\subsection{SUCCESS AND FAILURE FACTORS}

There were few positive and negative factors identified through the discussions with the key personnel of the Urban Development Authority and the manufacturer of the proposed solution. Altogether, 7 factors which can be causes for success of the proposed solution were identified; namely easy access to materials, lower production cost, saving of labour 
cost, lower transportation cost, conformance with building biology, recyclability and reusability and lower waste generation during production and demolition process. In addition, 8 factors which can be causes to failure of proposed solution were also identified as attitudinal influence of communities, high land consumption, cost of thermal insulation techniques, risk of electrical hazards, unexpected live load of dwellers, uncertainty of following maintenance procedure, shorter lifetime of the building and legal issues (refer Figure 2).

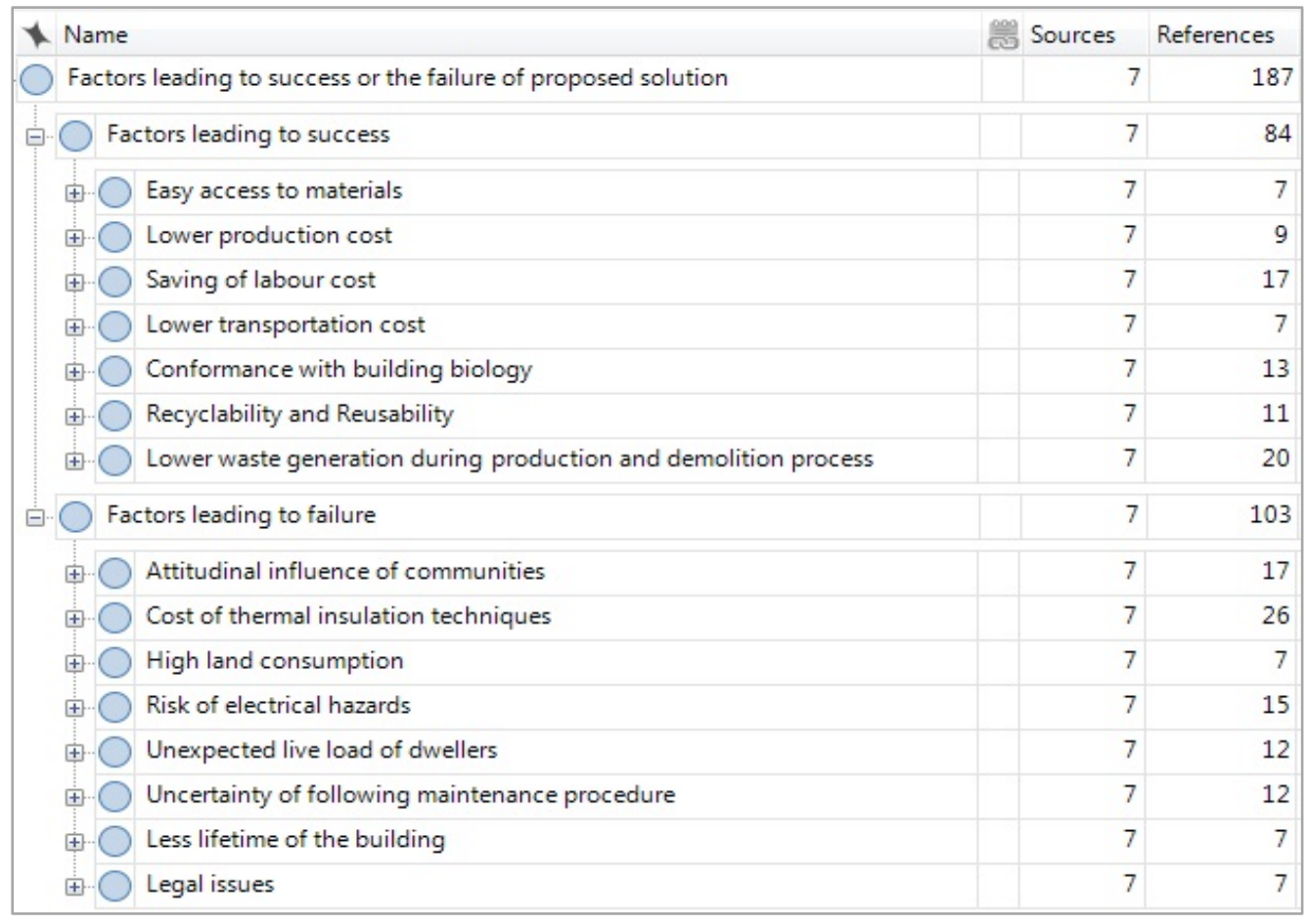

Figure 2: Coding of factors leading to success and failure of proposed solution

All the respondents highlighted that saving of labour cost of this proposed solution as an important characteristic. Lower waste generation and recyclability and reusability of material which have used for proposed solution were recommended as sustainable construction method. When it comes to failing factors, attitudinal influence was indicated as a factor which can directly causes to failure of the proposed solution. According to the authorities, less concern on the maintenance of the residences of this community will tend to reduce the life time of the proposed solution. High electricity conductivity of shipping container steel will be a high potential risk to users at lightning. Moreover, as a topical country Sri Lanka is having high temperature throughout the year. Therefore, thermal insulation cost is definitely higher. Land use for the proposed solution is considerably higher than the traditional housing scheme solution. Therefore, this fact will mislead the aim of this resettlement program which releasing of high potential prime lands from unauthorized, informal settled low income communities.

\section{CONCLUSIONS AND RECOMMENDATIONS}

In 2020, Urban Development Authority has a challenge to build rest of 52082 number of housing units which represent $76 \%$ of initial housing requirement. This revealed that, there is a huge gap between the demand and supply of this houses. Based on the cost 
comparison, carried out between $\mathrm{SCH}$ solution and the conventional housing, it discovered that more than $60 \%$ of construction cost can be saved by this proposed solution over the conventional housing solution. Further, these findings revealed that, the approximate cost saving that can obtain by using this proposed $\mathrm{SCH}$ unit as 143 billion and another $82226 \mathrm{SCH}$ units can be built utilizing that cost saving.

In Sri Lankan context, acceptance of this SCH solution by the low income community is at a lower level though the cost benefits are high. This study can be considered as a pilot study to evaluate the feasibility of using $\mathrm{SCH}$ concept as a LCH solution for permanent resettlement projects in Colombo region. However, through the industry practitioners and the Urban Development Authority personnel, there are few suggestions were proposed as using shipping container homes for post disaster housing, using modified shipping container boxes for self-employed shops for low income people and using shipping container buildings for commercial buildings and shopping malls as well.

\section{REFERENCES}

Abrasheva, G., Senk, D., and Haussling, R., 2012. Shipping containers for a sustainable habitat perspective. Revue De Metallurgie-Cahiers D Information Techniques, 109(5), pp.381-389.

Bolt, G., and Stănculescu, M. L., 2012. To an enclave-like city neighbourhood: case study of a development. University of Bucharest, Romania.

Brown, V. J., 2003. Give me shelter: The global housing crisis. Environmental Health Perspectives, 111(2), pp.92-99.

Cohen, R., and Bradley, M., 2010. Disasters and Displacement: Gaps in Protection. Journal of International Humanitarian Legal Studies, 1(1), pp.95-142.

Deheragoda, C., 2008. Meeting global challenges in research cooperation. In Addressing the Shelter Issue of Urban Poor: A Case Study from Sri Lanka, Uppsala, Sweden: Collegium of Development Studies, Uppsala University, pp.512-525.

Ford, G., Han, Y., Don, A., and Choi, M., 2014. Modular Building for Urban Disaster Housing: Case Study of Urban Post-Disaster Housing Prototype in New York, 28(6), pp.82-89.

Forrest, J., Hermes, K., Johnston, R., and Poulsen, M., 2013. The housing resettlement experience of refugee immigrants to Australia. Journal of Refugee Studies, 26(2), pp.187-206.

Islam, H., Zhang, G., Setunge, S., and Bhuiyan, M. A., 2016. Life cycle assessment of shipping container home: A sustainable construction. Energy and Buildings, 128, pp.673-685.

Joshi, S., and Sohail, M., 2014. Housing futures: housing for the poor in Sri-Lanka. Affordable Housing in the Urban Global South: Seeking Sustainable Solutions, pp.192-201.

Martinez-Garcia, M., 2014. Alternative Housing: The Shipping Container Home. National Association of Realtors, pp.1-3.

Meinhold, B., 2010. Pop-Up Village for Haiti Made From 900 Shipping Containers [online]. Available from https://inhabitat.com/pop-up-village-for-haiti-made-from-900-shipping-containers/ [Accessed 21 December 2017].

Ministry of Megapolis and Western Development, 2015. From island to continent-Western Region Master Plan Colombo, Ministry of Megapolis and Western Development.

Simon., 2014. Latest Shipping Container Housing Projects from around the World [online]. Available from http://www.containerteam.co.uk/latest-shipping-container-housing-projects-around-world [Accessed 21 December 2017].

United Nations High Commissioner for Refugees (UNHCR)., 2011. UNHCR Resettlement Handbook [online], pp.1-19. Available from http://www.unhcr.org/3c5e55594.html

Vijayalaxmi, J., 2010. Towards sustainable architecture - a case with Greentainer. Local Environment, 15(3), pp.245-259.

Wijayasinghe, S., 2010. Factors Contributing to the Failure of Development Induced Resettlement Projects: A Case Study of the Sahaspura Slum Relocation Project, Colombo, Sri Lanka. 
Winter, A., 2013. The charity that houses homeless people in shipping containers [online], Available from https://www.theguardian.com/housing-network/2013/oct/24/brighton-housing-homeless-shippingcontainers [Accessed 21 December 2012].

World Bank., 2004. Involuntary Resettlement Sourcebook - Planning and Implementation in Development Projects. Washington, DC 20433. 